\title{
Crocin Protects Podocytes Against Oxidative Stress and Inflammation Induced by High Glucose Through Inhibition of NF-KB
}

\author{
Sutong Lia Xiaoxia Liu ${ }^{b}$ Jie Lei ${ }^{a}$ Junle Yang ${ }^{c}$ Puxun Tiand Yi Gao \\ a Department of Nephropathy, ${ }^{b}$ Department of Endocrinology, cDepartment of Radiology, Xi'an Central \\ Hospital, dDepartment of Renal Transplantation, Kidney Disease Hospital of the First Affiliated Hospital \\ of Xi'an Jiaotong University, Xi'an, China
}

\section{Key Words}

Diabetic nephropathy $\cdot$ Crocin $•$ Podocytes $\cdot$ NF-kB

\begin{abstract}
Background/Aims: Diabetic nephropathy (DN) is a microangiopathic disease characterized by excessive urinary albumin excretion, which occurs in $30 \%$ of patients with diabetes mellitus. It is the second leading cause of end-stage renal diseases in China. Nuclear factor-kappa $\mathrm{B}(\mathrm{NF}-\mathrm{KB})$ is reported to be closely correlated with the inflammation underlying diabetesassociated renal damage. Crocin, a plant-derived compound, has antioxidant properties that may inhibit NF-kB. Methods: In the present study, we used a conditionally immortalized mouse podocyte cell line to explore whether crocin could effectively block albuminuria. Cells were incubated with 15 or 25 mM D-glucose to mimic diabetic conditions. The expression of Wilms tumor 1 (WT-1) and synaptopodin was evaluated to identify differentiated podocytes, and the expression of nephrin, podocin, and CD2ap was measured as markers of slit diaphragms, the main structures within the glomerular filtration barrier. Results: The high-glucose conditions led to reduced nephrin, podocin, and CD2ap expression, which was prevented by pretreatment with crocin. The oxidative stress and pro-inflammatory response of podocytes associated with DN induced by high glucose were also reduced by crocin pretreatment. Phosphorylated I $B \alpha(p-I \kappa B \alpha)$ expression induced by high glucose was also significantly decreased by crocin pretreatment. Moreover, pyrrolidine dithiocarbamate, a NF-KB inhibitor, pyrrolidine dithio carbamate, augmented the protective effects of crocin. Conclusion: Our results demonstrate a protective role of crocin against damage to podocytes and slit diaphragms under highglucose conditions via inhibition of NF-KB. This study presents a potential therapy for DN and contributes to the understanding of the mechanism underlying DN.
\end{abstract}

S. Li and X. Liu contributed equally to this study. 


\section{Introduction}

Diabetes mellitus (DM), a disease with complex mechanisms, is characterized by variable and aberrant glucose metabolism. Multiple complications are associated with DM, the most prevalent of which is nephropathy, with a morbidity of $25-40 \%[1,2]$. Diabetic nephropathy (DN), which is characterized by glomerular and tubular disorders, is a major microangiopathic complication of DM that occurs in up to $30 \%$ of patients [3]. Furthermore, DN is also a major cause of end-stage renal diseases (ESRD) in China, ranking second only to glomerulonephritis [4]. Once early DN has developed into ESRD, kidney failure is unavoidable and irreversible, requiring renal replacement therapy [5, 6]. Hence, early diagnosis, intervention, and treatment are critical for reversing or halting the progression of DN. Elevated proteinuria secretion $(20 \mu \mathrm{g} / \mathrm{min}<$ urine albumin excretion rate $<200 \mu \mathrm{g} / \mathrm{min})$ due to decreased glomerular filtration rate is the major clinical and recognized hallmark of early DN [7]. It results from damage to the filtration barrier by chronic hyperglycemia and the subsequent alteration of renal hemodynamics. The American Diabetes Association recommends strict glycemic control as the first-line method for the prevention of diabetic complications [5]; however, this approach does not completely prevent the progression of DN [8]. Moreover, while some therapeutic methods can relieve DN symptoms, including strict restriction of blood pressure, administration of angiotensin-converting enzyme inhibitors, and pharmacological suppression of the renin-angiotensin system, none of the available drugs are able to efficiently prevent or cure DN. Aside from the inadequacy of current drug therapies, knowledge of mechanisms underlying the progression of DN is also insufficient. Hence, investigation into the progression of DN and development of new drugs is urgently needed.

Podocytes (glomerular epithelial cells) are highly specialized and terminally differentiated cells that play an important role in the formation of the glomerular filtration barrier [9]; therefore, they are critical in protecting against proteinuria. The foot processes of podocytes are interlinked by slit diaphragms (SD), which are essential structures of the selective filtration barrier in glomeruli [10-12]. Changes in SD are generally associated with proteinuric diseases $[11,13]$. Because mature podocytes do not have a proliferative capacity, damage to these cells may induce continuous and irreversible albuminuria $[11,12]$. Studies have shown that podocytes are injured during the development of DN [14], hence, reducing podocyte injury has been proposed as an effective approach to prevent or slow the progression of DN.

Saffron (Crocus sativus L.) is a traditional Chinese medicine frequently used in clinical therapy for treatment of diseases [15], including, but not limited to, tumors [16], hypertension [17], insomnia and anxiety [18], cerebral ischemia [19], and depression [20]. Saffron extracts have been shown to have beneficial effects, including anti-tumor, antioxidation, anti-senescence, and pro-cardiovascular effects [21, 22]. As previously reported, crocin is one of the two most pharmacologically bioactive constituents found in gardenia fruits and saffron stigmas [23] with antioxidant properties, anti-apoptotic actions, and antiinflammatory effects being attributed to it $[24,25]$. However, whether crocin has a beneficial effect on podocytes remains unknown.

Numerous studies have shown that oxidative stress is a major contributor to the pathogenesis of DN [26, 27]. The kidney remodeling and tissue fibrosis induced by hyperglycemia-induced oxidative damage contribute greatly to the development and progression of DN [28]. Miranda-Diaz et al. reported an increase in reactive oxygen species (ROS) in diabetic mice with nephropathy [29], and Siddiqi et al. demonstrated oxidative injury in podocytes cultured under high-glucose conditions [30]. In addition, altered secretion of pro-inflammatory factors, including interleukin (IL)-8 and IL-10, is observed during the early stages of DN, and these factors are major contributors to the pathogenesis of DN [31]. Inhibition of podocyte inflammation induced by fructose [32] or lipopolysaccharides [33] appears to be a promising therapeutic strategy for the prevention of podocyte injury [34]. Whether crocin plays a similar role in relieving the oxidative stress and pro-inflammatory 
response of podocytes during the progression of DN is unclear. Nuclear factor-kappa B (NF$\kappa \mathrm{B})$ is a ubiquitous and important nuclear transcription factor that regulates the expression of a large number of genes involved in inflammation [35] and the inflammatory response [36]. Hence, it is also of great importance to explore the relationship between NF- $\mathrm{BB}$ and inflammation in podocytes, the understanding of which is limited.

In summary, it is well-known that podocyte injury disrupts the filtration barrier and contributes to albuminuria in patients with DN, but the impact of crocin and NF- $\kappa B$ on this process remains unknown. This study aimed to investigate whether crocin has a protective effect on podocytes cultured under hyperglycemic conditions, and if so, to elucidate the underlying mechanism and identify a potential therapeutic strategy for the treatment of DN.

\section{Materials and Methods}

\section{Culture of mouse podocytes}

Mouse podocytes were cultured as previously described [3, 37]. Briefly, to induce proliferation, culture dishes were precoated and incubated with type 1 collagen (Sigma, St. Louis, MO, USA) overnight, and cells were cultured in type 1 collagen-coated plates containing RPMI-1640 medium (Hyclone, Logan, UT, USA) supplemented with 10\% fetal bovine serum (FBS; Hyclone) and $10 \mathrm{U} / \mathrm{ml}$ interferon (IFN)- $\gamma$ (Sigma) at 33 ${ }^{\circ} \mathrm{C}$ with $5 \% \mathrm{CO}_{2}$. To induce differentiation, podocytes were cultured at $37{ }^{\circ} \mathrm{C}$ with $5 \% \mathrm{CO}_{2}$, without IFN- $\gamma$, for 14 days. Differentiated podocytes were serum starved for $24 \mathrm{~h}$ in RPMI-1640 medium containing $0.5 \%$ FBS prior to the experiments described below.

\section{Cell treatment}

To mimic in vivo diabetic conditions, differentiated podocytes were seeded in type 1 collagen-coated plates and cultured in medium supplemented with either 15 or 25 mM D-glucose (Sigma) for 7 days. Cells cultured in a normal glucose concentration ( $5 \mathrm{mM}$ D-glucose) served as the control. For certain groups, podocytes were pretreated with $0.1,0.5$, or $1 \mu \mathrm{M}$ of crocin (Sigma) for $24 \mathrm{~h}$ prior to exposure to high glucose. Some subsamples within the crocin-treated groups were pretreated with NF- $\kappa$ B inhibitor pyrrolidine dithiocarbamate (PDTC; $10 \mu \mathrm{M}$; Sigma) for $2 \mathrm{~h}$ prior to incubation with crocin $(0.1,0.5$, or $1 \mu \mathrm{M})$ for $24 \mathrm{~h}$, followed by incubation with D-glucose (15 or $25 \mathrm{mM})$.

\section{MTT assay}

The MTT assay was performed using a MTT Cell Proliferation and Cytotoxicity Assay Kit (Beyotime, Shanghai, China). Briefly, cells were seeded onto 96-well plates, followed by incubation with MTT solution for $48 \mathrm{~h}$, to which a dissolving solution was added to dissolve the formazan formed. The optical density (OD) value recorded at $490 \mathrm{~nm}$ was used to monitor cell viability.

\section{Reactive oxygen species assay}

The ROS assay was performed using a Reactive Oxygen Species Assay Kit (Beyotime). Briefly, cells were digested and harvested, then stained with dichloro-dihydro-fluorescein diacetate (DCFH-DA) according to the manufacturer's instructions. The signal was detected with an excitation wavelength of $488 \mathrm{~nm}$ and an emission wavelength of $525 \mathrm{~nm}$ by using flow cytometer (FACS Calibur, BD Biosciences, San Jose, CA, USA). Flow cytometry data were analyzed using CellQuest Pro software (BD Biosciences). Cells treated with ROSup only (provided with the kit) were used as the positive control.

Superoxide dismutase assay

The superoxide dismutase (SOD) assay was performed using a Total Superoxide Dismutase Assay Kit (Beyotime). Briefly, the supernatant obtained from cell homogenates was mixed with the working solution, and the mixtures were incubated at $37^{\circ} \mathrm{C}$ for $30 \mathrm{~min}$. The OD value was measured at $450 \mathrm{~nm}$. The SOD level was calculated according to the manufacturer's instructions.

ELISA

The protein levels of IL-1 $\beta$, IL-8, IL-10, and tumor necrosis factor (TNF)- $\alpha$ in cell supernatant were measured using ELISA kits (R\&D Systems, Minneapolis, MN, USA) according to the manufacturer's 
instructions. Briefly, cells were digested and centrifuged, and the culture supernatant was collected to determine the protein concentrations using a SmartSpec Plus spectrophotometer (Bio-Rad, Hercules, CA, USA).

\section{Quantitative PCR}

Total RNA was extracted using TRIzol $®$ Reagent (Invitrogen, Carlsbad, CA, USA) and reverse-transcribed into cDNA using SuperScript $®$ VILO cDNA Synthesis Kit and Master Mix (Invitrogen). Quantitative PCR was performed using SYBR® Fast qPCR Mix (Takara Biotechnology, Dalian, China) and a CFX96 Real-Time PCR System (Bio-Rad). All procedures were performed following the manufacturer's instructions. The relative expression compared to the reference gene $\beta$-actin was calculated using the $2^{-\Delta \Delta c t}$ method. The primer sequences are shown in Table 1.

\section{Western blotting}

Proteins were extracted using RIPA buffer (Sigma), then subjected to 10\% SDS-PAGE, followed by transfer onto nitrocellulose (NC) membranes (Merck Millipore, Billerica, MA, USA). After being blocked with $10 \%$ skim milk in TBS-T, the membrane was incubated with the primary antibodies in Table 2 overnight at $4{ }^{\circ} \mathrm{C}$. The membrane was then incubated with horseradish peroxidase-conjugated secondary antibodies (catalog No. G-21234, 1:2000, Invitrogen) for $2 \mathrm{~h}$ at room temperature. Bands were detected using an enhanced chemiluminescence kit (Invitrogen). The OD analysis was performed using Image-Pro Plus 6.0 (Media Cybernetics, Rockville, MD, USA).

\section{Statistical analysis}

Data are displayed as mean \pm standard deviation (SD). Comparison between two groups was performed using Student's $t$-test, and analysis of variance (ANOVA) was used for multiple groups. For all analyses, $p<$ 0.05 and $p<0.01$ indicated statistical significance. GraphPad Prism 5 software (GraphPad Software, Inc., La Jolla, CA, USA) and Adobe Photoshop CS2 software (Adobe Systems Incorporated, San Jose, CA, USA) were used to create Figures.

\section{Results}

Identification of differentiated podocytes

Podocytes were cultured at $33{ }^{\circ} \mathrm{C}$ in an undifferentiated state, then maintained at $37{ }^{\circ} \mathrm{C}$ to foster differentiation. Undifferentiated podocytes showed an epithelial-like cobblestone shape with small cell bodies (Fig. 1A). After thermoswitching to $37{ }^{\circ} \mathrm{C}$, the cell bodies enlarged, accompanied by the formation of foot processes and spindle-like projections and junctions. As shown in Fig. 1B, differentiated podocytes could be identified by their large arborized shape and foot processes and by expression of the
Table 1. Primer sequences used in this study

\begin{tabular}{|c|c|c|}
\hline Gene & Primer sequences (5'-3') & Product (bp) \\
\hline WT-1 & $\begin{array}{l}\text { Forward: ATCCCAGGCAGGAAAGTGTG } \\
\text { Reverse: TGCAGTCAATCAGGTGTGCT }\end{array}$ & 126 \\
\hline Synaptopodin & $\begin{array}{l}\text { Forward: CCGTGAGTCCCACTTACAGC } \\
\text { Reverse: CCTCACTAAGCCCCGAGCTA }\end{array}$ & 234 \\
\hline Nephrin & $\begin{array}{l}\text { Forward: TTGTAATGGGGCTTCTCCCA } \\
\text { Reverse: AACCTGCAACCCAAAATCTCAC }\end{array}$ & 397 \\
\hline Podocin & $\begin{array}{l}\text { Forward: TTGAGAATGGACAGCAGGGC } \\
\text { Reverse: TTGATGCCTTCCTCTGGTCG }\end{array}$ & 293 \\
\hline CD2ap & $\begin{array}{l}\text { Forward: ATGGCCTTGTGCTGTAGCAAT } \\
\text { Reverse: AAGGCAAGGTAGGCTAAACG }\end{array}$ & 123 \\
\hline$\beta$-actin & $\begin{array}{l}\text { Forward: TGAGCTGCGTTTTACACCCT } \\
\text { Reverse: TTTGGGGGATGTTTGCTCCA }\end{array}$ & 231 \\
\hline
\end{tabular}

Table 2. Primary antibodies used in this study

\begin{tabular}{|c|c|c|c|c|}
\hline Antibody & Host & Cat. No. & Dilution & Supplier \\
\hline WT-1 & Rabbit & PA1-20991 & $1: 1000$ & Invitrogen \\
\hline Synaptopodin & Rabbit & PA5-21062 & $1: 1000$ & Invitrogen \\
\hline Nephrin & Rabbit & PA5-20330 & $1: 1000$ & Invitrogen \\
\hline Podocin & Rabbit & PA5-37284 & $1: 500$ & Invitrogen \\
\hline CD2ap & Rabbit & PA5-28391 & $1: 1500$ & Invitrogen \\
\hline 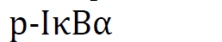 & Rabbit & PA5-38603 & $1: 1000$ & Invitrogen \\
\hline $\mathrm{I} \kappa \mathrm{B} \alpha$ & Rabbit & PA5-22120 & $1: 2000$ & Invitrogen \\
\hline$\beta$-actin & Rabbit & PA5-16914 & $1: 1000$ & Invitrogen \\
\hline
\end{tabular}



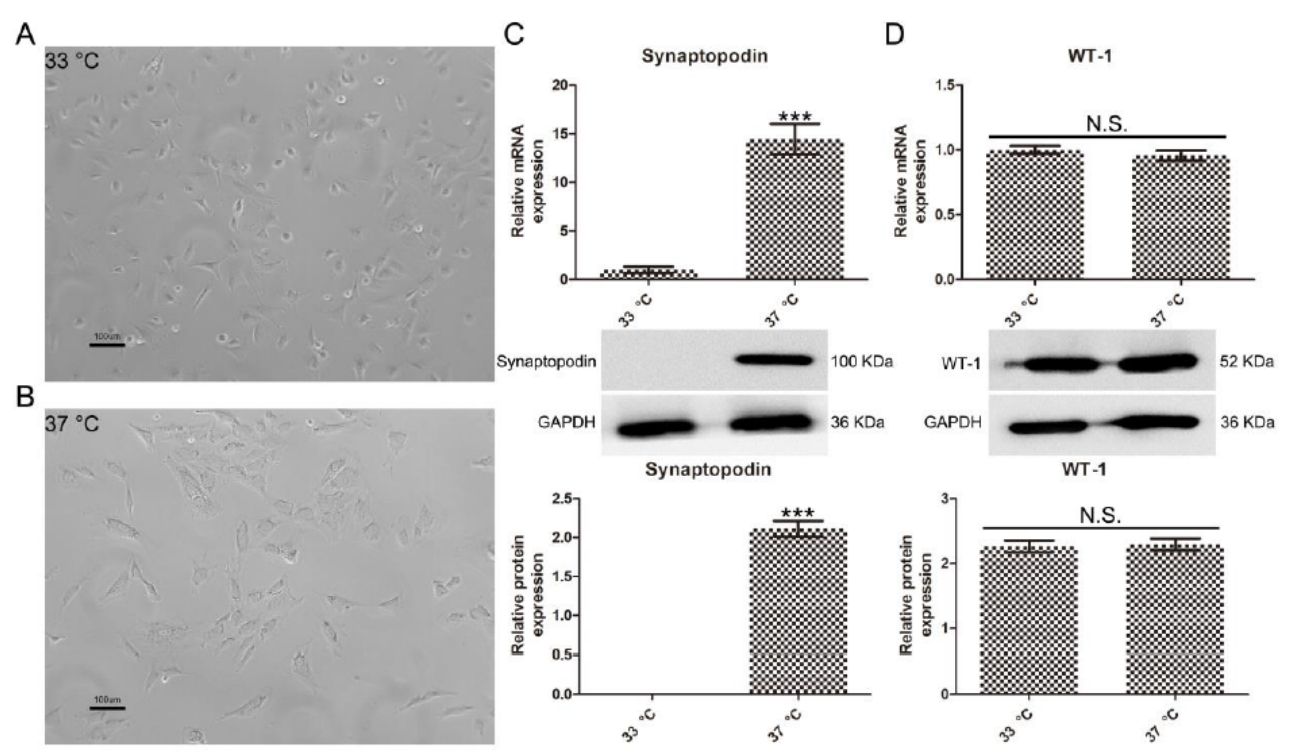

Fig. 1. Identification of differentiated podocytes. The morphology of podocytes cultured at $33{ }^{\circ} \mathrm{C}(\mathrm{A})$ and $37{ }^{\circ} \mathrm{C}(\mathrm{B})$. After thermoswitching to $37^{\circ} \mathrm{C}$, cells shifted from a cobblestone shape to an arborized shape. The mRNA and protein expression of synaptopodin (C) and WT-1 (D), as analyzed by quantitative PCR and Western blotting, respectively. Podocytes cultured at $37{ }^{\circ} \mathrm{C}$ expressed both WT-1 and synaptopodin, but there was no expression of synaptopodin at $33^{\circ} \mathrm{C} .{ }^{* * *}, p<0.01$; N.S., no statistical significance; Scale bars $=$ $100 \mu \mathrm{m}$.

Fig. 2. Construction of a diabetic model in podocytes. Cells were cultured in a medium supplemented with either 15 or $25 \mathrm{mM}$ D-glucose. Cells cultured in a normal glucose concentration (5 mM D-glucose) served as the control. Morphology of podocytes cultured under 5 $\mathrm{mM}$ (A), $15 \mathrm{mM}$ (B), and 25 $\mathrm{mM}$ D-glucose (C). Cells lost their intercellular junctions, with shorter foot processes and a smaller cell size. (D) The viability of podocytes was assessed by MTT assay. N.S., no statistical significance; Scale bars $=100 \mu \mathrm{m}$.

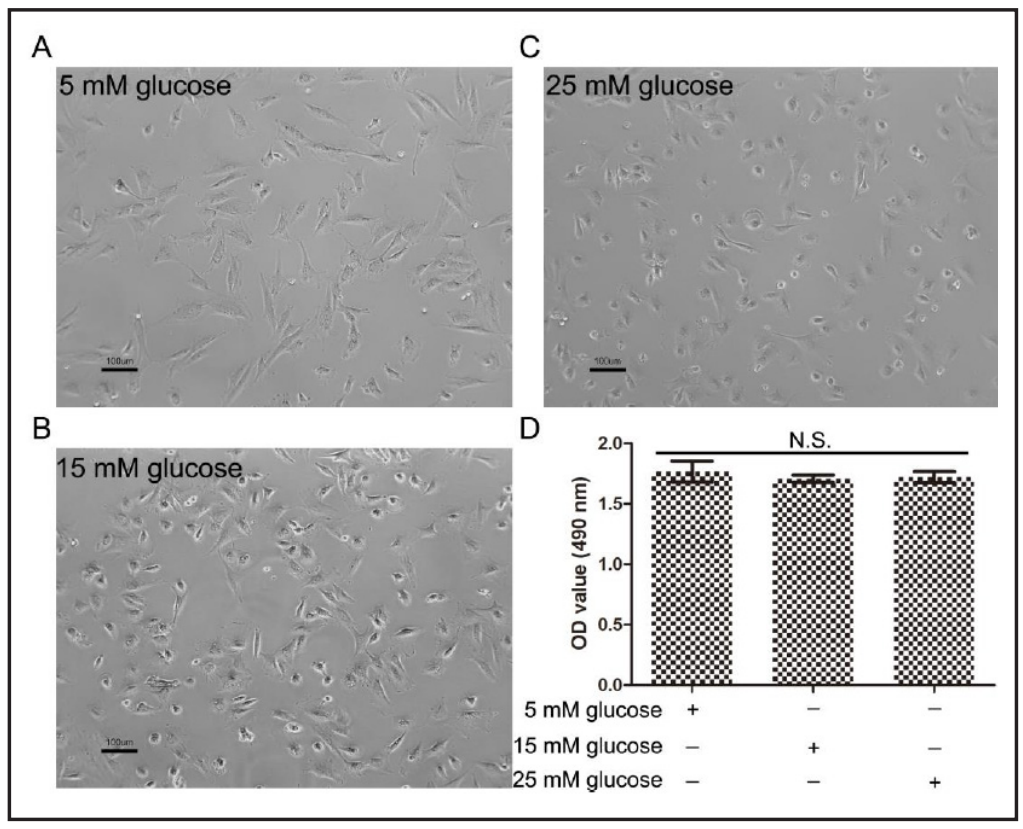

differentiation marker synaptopodin [38, 39] (Fig. 1C), which is not detected in undifferentiated cobblestone-shaped podocytes [40]. Both cobblestone and arborized cells originated from podocytes, as evidenced by expression of the podocyte-specific marker WT-1 [40, 41] (Fig. 1D).

\section{Construction of a diabetic model in podocytes}

The differentiated podocytes were cultured in medium supplemented with a high glucose concentration (15 or $25 \mathrm{mM}$ D-glucose) at $37^{\circ} \mathrm{C}$ to mimic diabetic conditions. As 


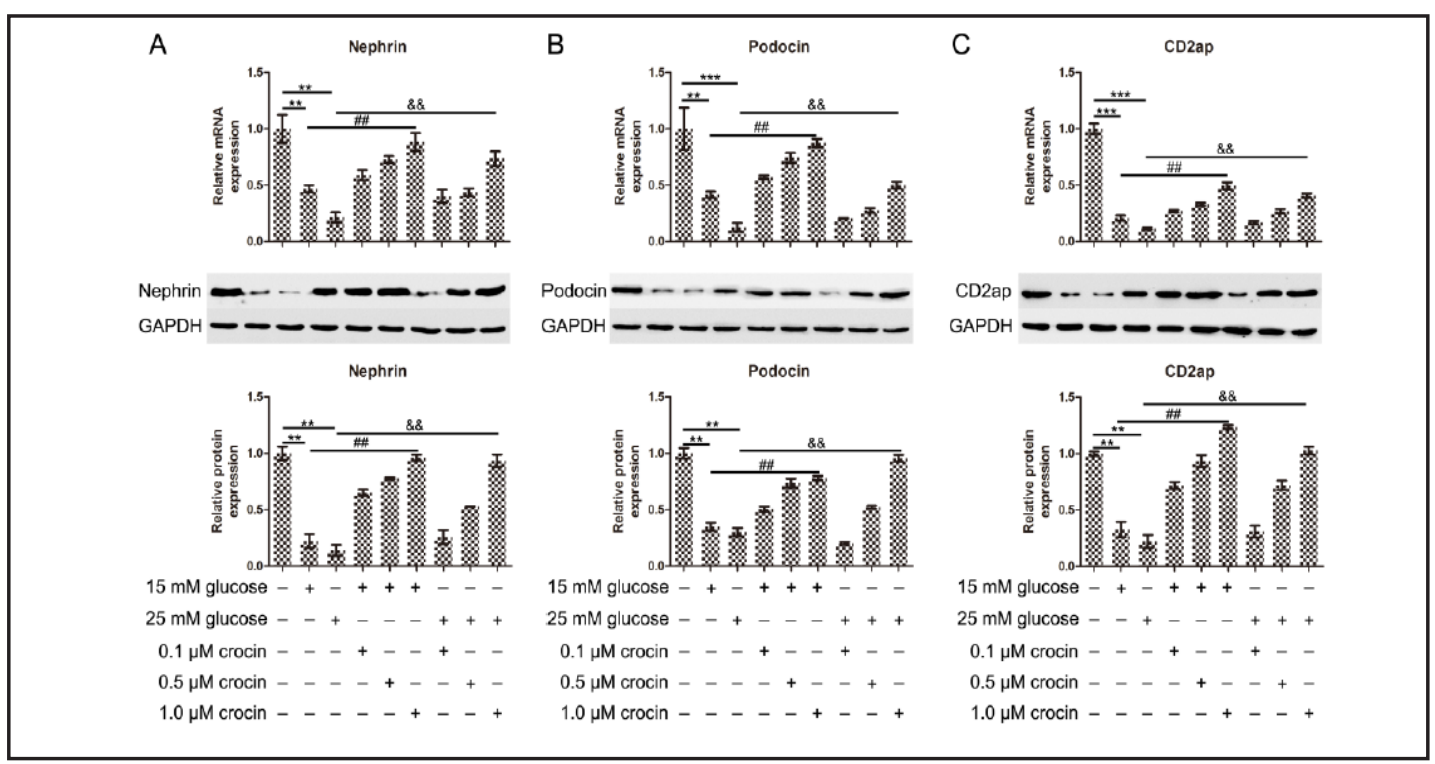

Fig. 3. Investigation of SD markers. The mRNA and protein expression of nephrin (A), podocin (B), and CD2ap (C) evaluated by quantitative PCR and Western blotting, respectively. High-glucose conditions significantly decreased the expression of these three genes, while crocin markedly restored their expression in a dose-dependent manner. ${ }^{* *}$ and \#\# and $\& \&, p<0.01 ; * * *, p<0.001$.

shown in Fig. 2A-C, cells lost their intercellular junctions after incubation with 15 or $25 \mathrm{mM}$ D-glucose, with shortened foot processes and a smaller cell size. In addition, the results of the MTT assay showed that podocytes cultured under 15 or $25 \mathrm{mM}$ D-glucose had similar viability compared with control cells (Fig. 2D), indicating that these cells could be used in the following experiments.

\section{Evaluation of SD markers}

Nephrin, podocin, and CD2ap are key markers for SD $[13,41]$. The mRNA and protein expression of these three genes was investigated to explore the variation of SD under diabetic conditions. As shown in Fig. 3, high-glucose conditions induced a significant decrease in nephrin expression (Fig. 3A), in addition to markedly down-regulated expression of podocin (Fig. 3B) and CD2ap (Fig. 3C) at the mRNA level. Moreover, the protein expression of SD markers was also confirmed to be notably decreased, as evaluated by Western blotting and OD analysis. The effects of $0.1,0.5$, or $1 \mu \mathrm{M}$ of crocin were explored in this study. Crocin showed a dose-dependent prevention of the inhibitory effects of high glucose on SD markers, indicating that crocin has a protective role in SD.

\section{Evaluation of oxidative stress and pro-inflammatory response}

Because we identified a protective role of crocin in SD, we explored the mechanism involved by evaluating the effect of crocin on oxidation and inflammation induced by high glucose. Unsurprisingly, 15 or $25 \mathrm{mM}$ D-glucose significantly up-regulated the levels of ROS (Fig. 4A) but inhibited the production of SOD (Fig. 4B). Similarly, the levels of proinflammatory factors, including IL-1 $\beta$ (Fig. 4C), IL-8 (Fig. 4D), IL-10 (Fig. 4E), and TNF- $\alpha$ (Fig. $4 \mathrm{~F}$ ), were remarkably increased in podocytes after incubation with 15 or $25 \mathrm{mM}$ D-glucose.

In contrast, crocin demonstrated protective effects on podocytes by significantly inhibiting ROS production and restoring SOD levels in a dose-dependent manner. In addition, crocin notably blocked the release of IL-1 $\beta$, IL-8, IL-10, and TNF- $\alpha$ induced by the hyperglycemic conditions, as expected, thus inhibiting the pro-inflammatory response. Morphological alterations of podocytes after treatment with crocin were also observed. Podocytes treated with crocin demonstrated more branches even cultured under $15 \mathrm{mM}$ 


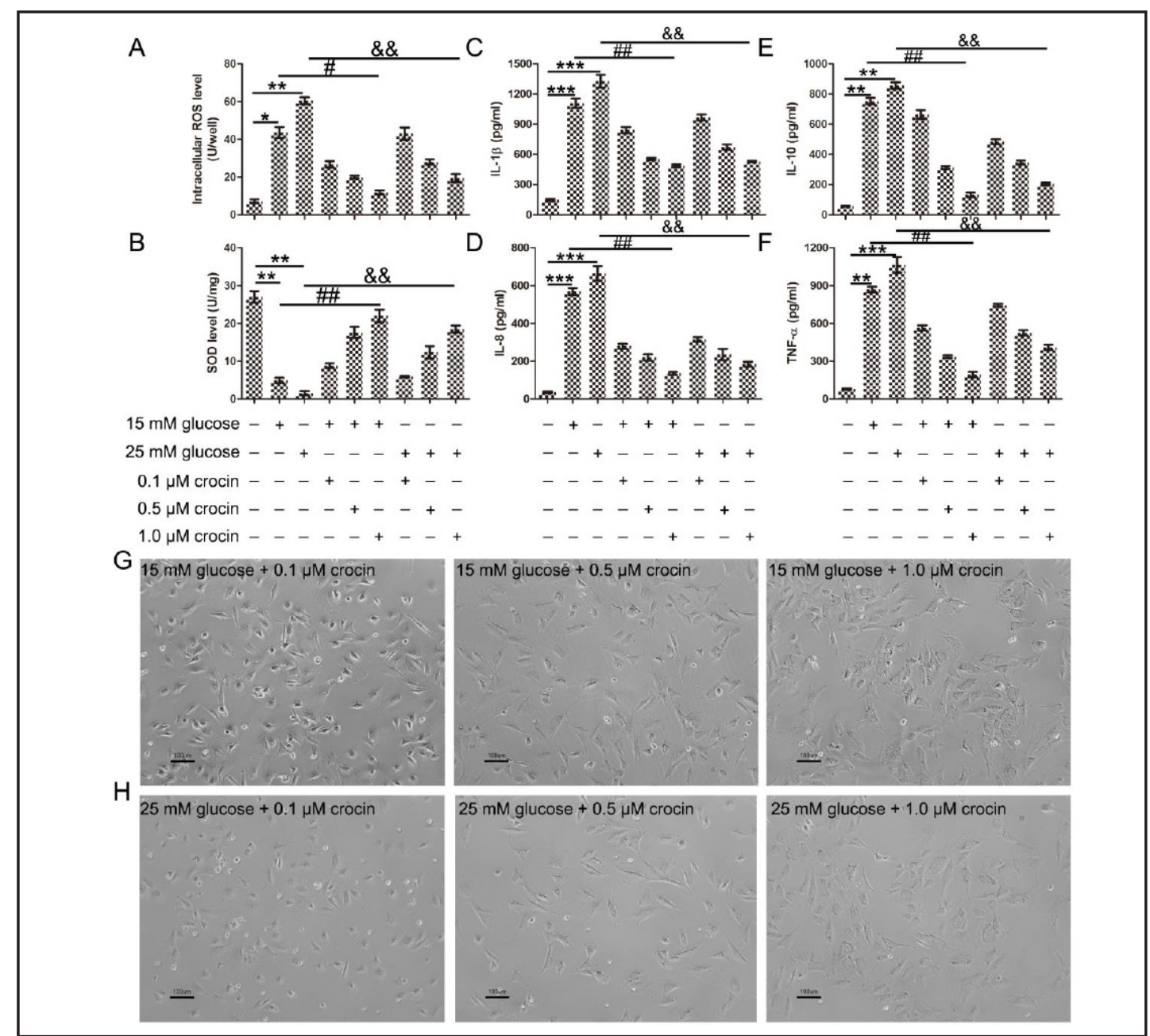

Fig. 4. Evaluation of oxidative stress and inflammatory response. Levels of reactive oxygen species (ROS; A) and superoxide dismutase (SOD; B). The pro-inflammatory factors IL-1 $\beta$ (C), IL-8 (D), IL-10 (E) and TNF- $\alpha$ (F) were also measured by ELISA. In general, the oxidative stress and inflammation induced by high-glucose conditions were significantly ameliorated by crocin treatment in a dose-dependent manner. Podocytes cultured under $15 \mathrm{mM}(\mathrm{G})$ or $25 \mathrm{mM}(\mathrm{H})$ glucose went through a morphological alteration from an unbranched and smaller shape to a branched and larger shape with pretreatment with crocin. ${ }^{*}$ and $\#, p<0.05 ;{ }^{* *}$ and \#\# and $\& \&, p<0.01 ;{ }^{* *}, p<0.001$; Scale bars $=100 \mu \mathrm{m}$.

(Fig. 4G) and $25 \mathrm{mM}$ (Fig. 4H) glucose in a dose-dependent manner. In summary, crocin reversed the harmful effects of hyperglycemia on podocytes in a dose-dependent manner, thus demonstrating its positive role in reducing podocyte injury.

\section{Evaluation of NF- $\kappa B$ signaling}

As mentioned previously, NF- $\kappa \mathrm{B}$ is closely related to the pro-inflammatory responses that usually trigger inflammation [36]. Hence, in this study, we studied NF- $\mathrm{BB}$ signaling to investigate its degree of involvement. NF- $\kappa B$ inhibitor PDTC $(10 \mu \mathrm{M})$ was used to treat podocytes, along with $1 \mu \mathrm{M}$ of crocin and $25 \mathrm{mM}$ of D-glucose, the concentrations of which were selected based on above studies. As shown in Fig. $5 \mathrm{~A}$ and $\mathrm{B}$, phosphorylated IкB $\alpha$ $(\mathrm{p}-\mathrm{I} \kappa \mathrm{B} \alpha$ ) expression was significantly up-regulated under high-glucose conditions, but markedly inhibited by pretreatment with $1 \mu \mathrm{M}$ of crocin. PDTC further decreased the p-IкB $\alpha$ level immensely, which consequently down-regulated the levels of IL-1 $\beta$ (Fig. 5C) and TNF- $\alpha$

\section{KARGER}




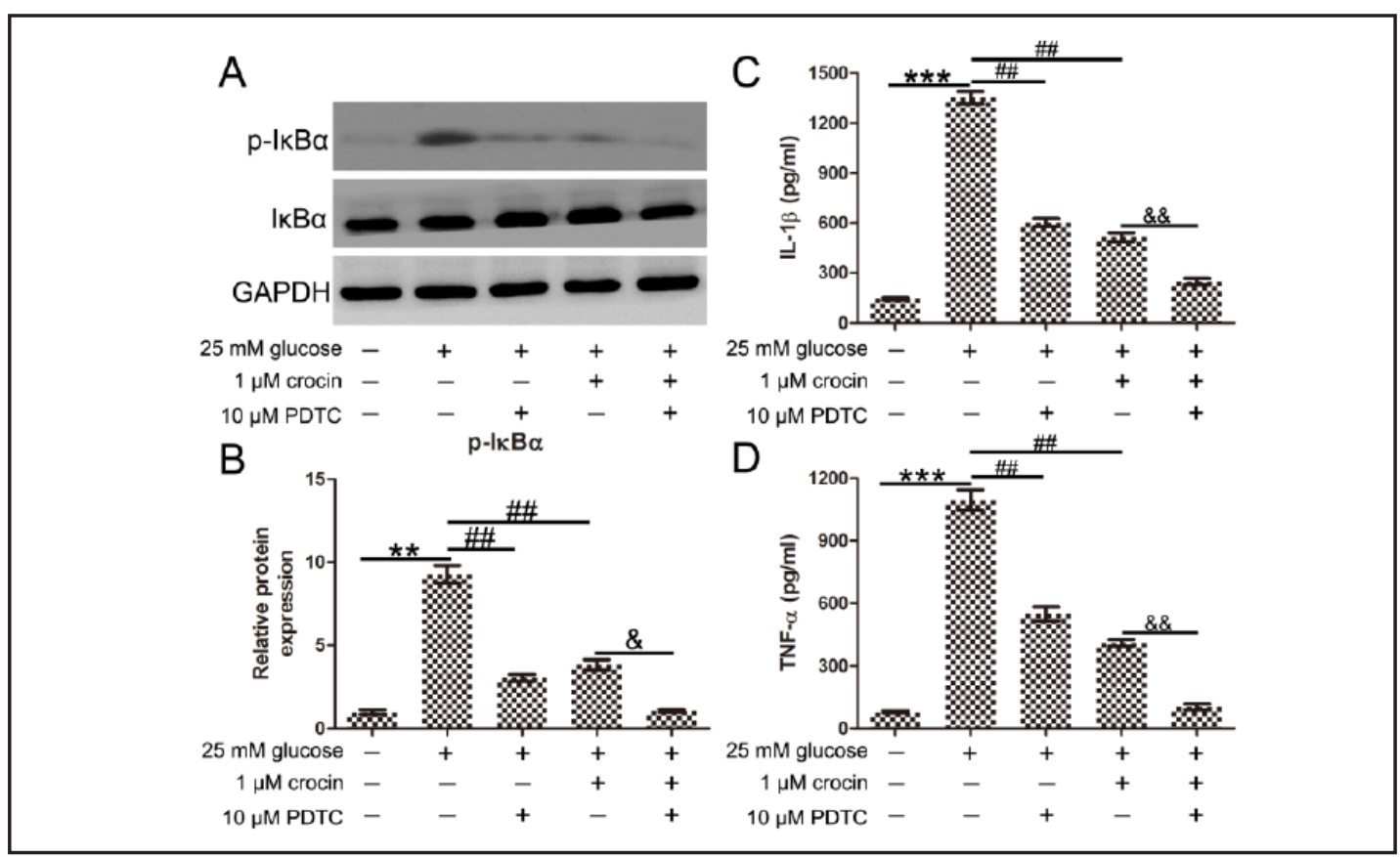

Fig. 5. Assessment of NF- $\kappa B$ involvement. Podocytes were treated with the NF- $\kappa B$ inhibitor pyrrolidine dithio carbamate (PDTC; $10 \mu \mathrm{M})$, crocin $(1 \mu \mathrm{M})$ and D-glucose $(25 \mathrm{mM})$. (A) Protein expression of $\mathrm{p}$-IкB $\alpha$

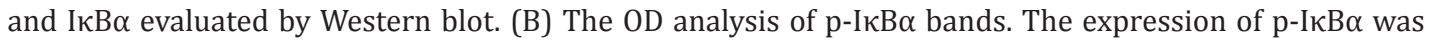
promoted by $25 \mathrm{mM}$ of D-glucose, but inhibited by $1 \mu \mathrm{M}$ of crocin and $10 \mu \mathrm{M}$ of PDTC. The levels of IL-1 13 (C) and TNF- $\alpha$ (D) were decreased by PDTC, which reinforced the effect of crocin. ${ }^{*}, p<0.05 ;{ }^{* *}, p<0.01$.

(Fig. 5D). These results indicate that crocin inhibits oxidative stress and the inflammatory response of podocytes through inhibition of NF- $\kappa B$.

\section{Discussion}

The present study focused on an evaluation of podocytes under culture conditions that mimicked in vivo diabetic conditions. High levels of glucose were used to model DN in podocytes. The results showed that under hyperglycemic conditions, podocytes underwent oxidative stress and an inflammatory response, which appeared to strongly contribute to the destruction of SD (measured as decreased nephrin, podocin and CD2ap expression). Moreover, crocin demonstrated a protective role in SD, with significantly inhibited oxidative stress and decreased levels of IL-1 $\beta$, IL-8, IL-10, and TNF- $\alpha$. We suspected that the mechanism involved may be through the inhibition of NF- $\mathrm{\kappa B}$.

Synaptopodin is a biomarker of differentiated podocytes [38], and its expression of synaptopodin gradually increases during nephrogenesis and podocyte differentiation. Synaptopodin is involved in the formation of foot processes along with actin filaments [40], and it plays a significant role in the development and maintenance of these structures. Interestingly, both undifferentiated and differentiated podocytes express WT-1, another podocyte biomarker [39]. Podocytes are terminally differentiated cells in mature glomeruli. Cultured immortalized podocytes proliferate at $33^{\circ} \mathrm{C}$ and differentiate at $37{ }^{\circ} \mathrm{C}$ [41]. As shown in Fig. 1B, podocytes cultured at $37^{\circ} \mathrm{C}$ exhibited more spindle-shape branches and intercellular junctions compared with cells at $33^{\circ} \mathrm{C}$ (Fig. 1A). Podocytes cultured at $37^{\circ} \mathrm{C}$ also had increased expression of synaptopodin (Fig. 1C), indicating that the podocytes used in the following experiments were in a differentiated state. 
Early DN is characterized by excessive proteinuria, due to the destruction of SD and foot processes formed by podocytes [42]. Hence, maintaining the structural integrity of SD is expected to be important for preventing or slowing DN. Nephrin is a transmembrane zipperlike protein located at the SD, which guarantees the correct arrangement of the glomerular basement membrane and the podocytes $[12,43]$. Mutation of the NPHS1 gene, which encodes nephrin, has been reported to cause the fusion of foot processes and loss of SD in mice [44]. Similarly, other studies have shown that knock-down of the podocin encoding gene NPHS2 also led to proteinuria and death of mice, which was associated with the fusion of foot processes and the destruction of SD [10,45]. Podocin is localized together with nephrin on the membranes to form the filtration barriers. In addition, deletion of the CD2ap gene, a cytoplasmic binding protein of nephrin involved in the regulation of the podocyte cytoskeleton and the stabilization of SD, led to the development of proteinuria and fusion of the foot processes in mice [46]. Consequently, nephrin, podocin, and CD2ap were selected as the markers for SD in the current study. Decreased expression of these three genes indicated dysfunction of SD in podocytes. These results are consistent with studies by Saleem et al. [41] and Fukasawa et al.[13]. The beneficial effects of crocin on SD were confirmed through evaluation of nephrin, podocin, and CD2ap at both the mRNA and protein levels.

Oxidative stress is emerging as a critical event and mediator of DN [29]. In diabetes, oxidative damage occurs when there is an imbalance between ROS generation and production of antioxidant enzyme [28]. The IL-8 and IL-10 levels have also been reported to be significantly altered in the early pathogenesis of DN [31,47]. Consequently, oxidative stress and inflammation are two major factors associated with the pathogenesis of DN [27]. Our results provide evidence that crocin could potentially counteract the oxidation and inflammation induced by high-glucose conditions, because crocin was found to play a protective role in podocytes.

$\mathrm{NF}-\mathrm{\kappa B}$ is a crucial nuclear transcription factor that is closely involved in the regulation of the inflammatory response [48]. NF- $\kappa \mathrm{B}$ is bound within the cytoplasm via interactions with the I $\kappa$ B family of inhibitory proteins. When cells receive harmful stimuli, the I $\kappa$ B proteins are immediately phosphorylated [36], resulting in exposure of nuclear localization signals on the NF- $\kappa B$ subunits. The sequestered NF- $\kappa B$ is freed and translocates to the nucleus, where it induces the production of pro-inflammatory factors, such as TNF- $\alpha$ and IL-1 $\beta$ [49]. As

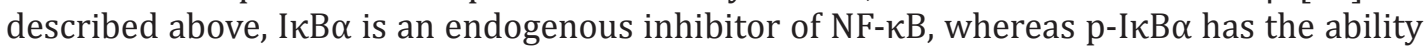
to activate NF- $\kappa B$. In this study, $\mathrm{p}-\mathrm{I} \kappa \mathrm{B} \alpha$ expression was notably inhibited by crocin and PDTC, as shown in Fig. 5A and B, indicating that both were both able to suppress NF- $\kappa$ B. As reported previously, IL-1 $\beta$ and TNF- $\alpha$ are the target genes for NF- $\kappa B$ [50]. Hence, these two inflammatory factors were further studied to investigate the role of NF- $\mathrm{KB}$ in podocytes under diabetic conditions, as shown in Fig. 5C and D. The results showed that PDTC reinforced the inhibitory effects of crocin on the glucose-induced expression of IL-1 $\beta$ and TNF- $\alpha$, suggesting that crocin prevented podocyte injury through the regulation of NF- $\kappa \mathrm{B}$. Taken together, our results demonstrate that crocin prevents high glucose-induced oxidation and inflammation of podocytes through inhibition of NF- $\mathrm{KB}$, providing a new therapeutic strategy for DN and associated podocyte injuries.

\section{Acknowledgements}

This study was supported by the Science and Technology Plan Program of Health Bureau of Xi'an [2013002].

\section{Disclosure Statement}

The authors declare that they have no conflict of interest. 


\section{Cellular Physiology Cell Physiol Biochem 2017;42:1481-1492 \begin{tabular}{l|l} 
and Biochemistry Published online: July 18, 2017 & $\begin{array}{l}\text { (c) } 2017 \text { The Author(s). Published by S. Karger AG, Basel } \\
\text { www.karger.com/cpb }\end{array}$
\end{tabular}}

Li et al.: Crocin Protects Podocytes via Inhibiting NF-kB

\section{References}

1 Ritz E, Schmieder RE, Pollock CA: Renal protection in diabetes: lessons from ONTARGET. Cardiovasc Diabetol 2010;9:60.

2 Chen L, Magliano DJ, Zimmet PZ: The worldwide epidemiology of type 2 diabetes mellitus--present and future perspectives. Nat Rev Endocrinol 2011;8:228-236.

-3 Chen YQ, Wang XX, Yao XM, Zhang DL, Yang XF, Tian SF, Wang NS: MicroRNA-195 promotes apoptosis in mouse podocytes via enhanced caspase activity driven by BCL2 insufficiency. Am J Nephrol 2011;34:549559.

-4 Wan Q, Xu Y, Dong E: Diabetic nephropathy research in China: Data analysis and review from the National Natural Science Foundation of China. J Diabetes 2015;7:307-314.

D'Addio F, Trevisani A, Ben Nasr M, Bassi R, El Essawy B, Abdi R, Secchi A, Fiorina P: Harnessing the immunological properties of stem cells as a therapeutic option for diabetic nephropathy. Acta Diabetol 2014;51:897-904.

6 Williams WW, Salem RM, McKnight AJ, Sandholm N, Forsblom C, Taylor A, Guiducci C, McAteer JB, McKay GJ, Isakova T, Brennan EP, Sadlier DM, Palmer C, Soderlund J, Fagerholm E, Harjutsalo V, Lithovius R, Gordin D, Hietala K, Kyto J, Parkkonen M, Rosengard-Barlund M, Thorn L, Syreeni A, Tolonen N, Saraheimo M, Waden J, Pitkaniemi J, Sarti C, Tuomilehto J, Tryggvason K, Osterholm AM, He B, Bain S, Martin F, Godson C, Hirschhorn JN, Maxwell AP, Groop PH, Florez JC: Association testing of previously reported variants in a large case-control meta-analysis of diabetic nephropathy. Diabetes 2012;61:2187-2194.

7 Marikanty RK, Gupta MK, Cherukuvada SV, Kompella SS, Prayaga AK, Konda S, Polisetty RV, Idris MM, Rao PV, Chandak GR, Dakshinamurty KV: Identification of urinary proteins potentially associated with diabetic kidney disease. Indian J Nephrol 2016;26:434-445.

8 Baban B, Liu JY, Payne S, Abebe W, Yu JC, Mozaffari MS: Status of stem cells in diabetic nephropathy: predictive and preventive potentials. EPMA J 2016;7:21.

-9 Chen T, Zheng LY, Xiao W, Gui D, Wang X, Wang N: Emodin ameliorates high glucose induced-podocyte epithelial-mesenchymal transition in-vitro and in-vivo. Cell Physiol Biochem 2015;35:1425-1436.

10 Boute N, Gribouval O, Roselli S, Benessy F, Lee H, Fuchshuber A, Dahan K, Gubler MC, Niaudet P, Antignac C: NPHS2, encoding the glomerular protein podocin, is mutated in autosomal recessive steroid-resistant nephrotic syndrome. Nat Genet 2000;24:349-354.

11 Zhang HT, Wang WW, Ren LH, Zhao XX, Wang ZH, Zhuang DL, Bai YN: The mTORC2/Akt/NFkappaB Pathway-Mediated Activation of TRPC6 Participates in Adriamycin-Induced Podocyte Apoptosis. Cell Physiol Biochem 2016;40:1079-1093.

12 Liu Y, Su L, Lin Q, Han Y, You P, Fan Q: Induction of C-Mip by IL-17 Plays an Important Role in AdriamycinInduced Podocyte Damage. Cell Physiol Biochem 2015;36:1274-1290.

13 Fukasawa H, Bornheimer S, Kudlicka K, Farquhar MG: Slit diaphragms contain tight junction proteins. J Am Soc Nephrol 2009;20:1491-1503.

14 Wolf G, Chen S, Ziyadeh FN: From the periphery of the glomerular capillary wall toward the center of disease: podocyte injury comes of age in diabetic nephropathy. Diabetes 2005;54:1626-1634.

15 Huynh TP, Mann SN, Mandal NA: Botanical compounds: effects on major eye diseases. Evid Based Complement Alternat Med 2013;2013:549174.

-16 Abdullaev FI, Espinosa-Aguirre JJ: Biomedical properties of saffron and its potential use in cancer therapy and chemoprevention trials. Cancer Detect Prev 2004;28:426-432.

17 Imenshahidi M, Hosseinzadeh H, Javadpour Y: Hypotensive effect of aqueous saffron extract (Crocus sativus L.) and its constituents, safranal and crocin, in normotensive and hypertensive rats. Phytother Res 2010;24:990-994.

18 Hosseinzadeh H, Noraei NB: Anxiolytic and hypnotic effect of Crocus sativus aqueous extract and its constituents, crocin and safranal, in mice. Phytother Res 2009;23:768-774.

19 Hosseinzadeh H, Sadeghnia HR, Ghaeni FA, Motamedshariaty VS, Mohajeri SA: Effects of saffron (Crocus sativus L.) and its active constituent, crocin, on recognition and spatial memory after chronic cerebral hypoperfusion in rats. Phytother Res 2012;26:381-386.

20 Akhondzadeh Basti A, Moshiri E, Noorbala AA, Jamshidi AH, Abbasi SH, Akhondzadeh S: Comparison of petal of Crocus sativus L. and fluoxetine in the treatment of depressed outpatients: a pilot double-blind randomized trial. Prog Neuropsychopharmacol Biol Psychiatry 2007;31:439-442. 


\section{Cellular Physiology Cell Physiol Biochem 2017;42:1481-1492 \begin{tabular}{l|l} 
DOI: 10.1159/000479212 & $\begin{array}{l}\text { O 2017 The Author(s). Published by S. Karger AG, Basel } \\
\text { www.karger.com/cpb }\end{array}$
\end{tabular}}

21 Ochiai T, Shimeno H, Mishima K, Iwasaki K, Fujiwara M, Tanaka H, Shoyama Y, Toda A, Eyanagi R, Soeda S: Protective effects of carotenoids from saffron on neuronal injury in vitro and in vivo. Biochim Biophys Acta 2007;1770:578-584.

22 Bolhassani A, Khavari A, Bathaie SZ: Saffron and natural carotenoids: Biochemical activities and anti-tumor effects. Biochim Biophys Acta 2014;1845:20-30.

23 Lee IA, Lee JH, Baek NI, Kim DH: Antihyperlipidemic effect of crocin isolated from the fructus of Gardenia jasminoides and its metabolite Crocetin. Biol Pharm Bull 2005;28:2106-2110.

24 Soeda S, Ochiai T, Paopong L, Tanaka H, Shoyama Y, Shimeno H: Crocin suppresses tumor necrosis factoralpha-induced cell death of neuronally differentiated PC-12 cells. Life Sci 2001;69:2887-2898.

-25 Ochiai T, Soeda S, Ohno S, Tanaka H, Shoyama Y, Shimeno H: Crocin prevents the death of PC-12 cells through sphingomyelinase-ceramide signaling by increasing glutathione synthesis. Neurochem Int 2004;44:321-330.

26 Khatami PG, Soleimani A, Sharifi N, Aghadavod E, Asemi Z: The effects of high-dose vitamin E supplementation on biomarkers of kidney injury, inflammation, and oxidative stress in patients with diabetic nephropathy: A randomized, double-blind, placebo-controlled trial. J Clin Lipidol 2016;10:922929.

27 Bahmani F, Kia M, Soleimani A, Mohammadi AA, Asemi Z: The effects of selenium supplementation on biomarkers of inflammation and oxidative stress in patients with diabetic nephropathy: a randomised, double-blind, placebo-controlled trial. Br J Nutr 2016;116:1222-1228.

28 Fernandes SM, Cordeiro PM, Watanabe M, Fonseca CD, Vattimo MF: The role of oxidative stress in streptozotocin-induced diabetic nephropathy in rats. Arch Endocrinol Metab 2016;60:443-449.

29 Miranda-Diaz AG, Pazarin-Villasenor L, Yanowsky-Escatell FG, Andrade-Sierra J: Oxidative Stress in Diabetic Nephropathy with Early Chronic Kidney Disease. J Diabetes Res 2016;2016:7047238.

-30 Siddiqi FS, Majumder S, Thai K, Abdalla M, Hu P, Advani SL, White KE, Bowskill BB, Guarna G, Dos Santos CC, Connelly KA, Advani A: The Histone Methyltransferase Enzyme Enhancer of Zeste Homolog 2 Protects against Podocyte Oxidative Stress and Renal Injury in Diabetes. J Am Soc Nephrol 2016;27:2021-2034.

-31 Tashiro K, Koyanagi I, Saitoh A, Shimizu A, Shike T, Ishiguro C, Koizumi M, Funabiki K, Horikoshi S, Shirato I, Tomino Y: Urinary levels of monocyte chemoattractant protein-1 (MCP-1) and interleukin-8 (IL-8), and renal injuries in patients with type 2 diabetic nephropathy. J Clin Lab Anal 2002;16:1-4.

- 32 Wang W, Ding XQ, Gu TT, Song L, Li JM, Xue QC, Kong LD: Pterostilbene and allopurinol reduce fructoseinduced podocyte oxidative stress and inflammation via microRNA-377. Free Radic Biol Med 2015;83:214226.

33 Ishibashi R, Takemoto M, Akimoto Y, Ishikawa T, He P, Maezawa Y, Sakamoto K, Tsurutani Y, Ide S, Ide K, Kawamura H, Kobayashi K, Tokuyama H, Tryggvason K, Betsholtz C, Yokote K: A novel podocyte gene, semaphorin 3G, protects glomerular podocyte from lipopolysaccharide-induced inflammation. Sci Rep 2016;6:25955.

-34 Bao XH, Xu J, Chen Y, Yang CL, Ye SD: Alleviation of podocyte injury: the possible pathway implicated in anti-inflammation of alpha-lipoic acid in type 2 diabetics. Aging Clin Exp Res 2014;26:483-489.

-35 Barroso E, Eyre E, Palomer X, Vazquez-Carrera M: The peroxisome proliferator-activated receptor beta/ delta (PPARbeta/delta) agonist GW501516 prevents TNF-alpha-induced NF-kappaB activation in human HaCaT cells by reducing p65 acetylation through AMPK and SIRT1. Biochem Pharmacol 2011;81:534-543.

-36 Hoesel B, Schmid JA: The complexity of NF-kappaB signaling in inflammation and cancer. Mol Cancer 2013;12:86.

-37 Kato M, Yuan H, Xu ZG, Lanting L, Li SL, Wang M, Hu MC, Reddy MA, Natarajan R: Role of the Akt/FoxO3a pathway in TGF-beta1-mediated mesangial cell dysfunction: a novel mechanism related to diabetic kidney disease. J Am Soc Nephrol 2006;17:3325-3335.

38 Shankland SJ, Pippin JW, Reiser J, Mundel P: Podocytes in culture: past, present, and future. Kidney Int 2007;72:26-36.

-39 Mundel P, Reiser J, Zuniga Mejia Borja A, Pavenstadt H, Davidson GR, Kriz W, Zeller R: Rearrangements of the cytoskeleton and cell contacts induce process formation during differentiation of conditionally immortalized mouse podocyte cell lines. Exp Cell Res 1997;236:248-258.

40 Mundel P, Reiser J, Kriz W: Induction of differentiation in cultured rat and human podocytes. J Am Soc Nephrol 1997;8:697-705. 


\section{Cellular Physiology Cell Physiol Biochem 2017;42:1481-1492 \begin{tabular}{l|l} 
DOI: 10.1159/000479212 & $\begin{array}{l}\text { O 2017 The Author(s). Published by S. Karger AG, Basel } \\
\text { www.karger.com/cpb }\end{array}$
\end{tabular}}

Li et al.: Crocin Protects Podocytes via Inhibiting NF-KB

41 Saleem MA, O'Hare MJ, Reiser J, Coward RJ, Inward CD, Farren T, Xing CY, Ni L, Mathieson PW, Mundel P: A conditionally immortalized human podocyte cell line demonstrating nephrin and podocin expression. J Am Soc Nephrol 2002;13:630-638.

42 Arif E, Rathore YS, Kumari B, Ashish F, Wong HN, Holzman LB, Nihalani D: Slit diaphragm protein Neph1 and its signaling: a novel therapeutic target for protection of podocytes against glomerular injury. J Biol Chem 2014;289:9502-9518.

43 Kestila M, Lenkkeri U, Mannikko M, Lamerdin J, McCready P, Putaala H, Ruotsalainen V, Morita T, Nissinen M, Herva R, Kashtan CE, Peltonen L, Holmberg C, Olsen A, Tryggvason K: Positionally cloned gene for a novel glomerular protein--nephrin--is mutated in congenital nephrotic syndrome. Mol Cell 1998;1:575582.

44 Patrakka J, Kestila M, Wartiovaara J, Ruotsalainen V, Tissari P, Lenkkeri U, Mannikko M, Visapaa I, Holmberg C, Rapola J, Tryggvason K, Jalanko H: Congenital nephrotic syndrome (NPHS1): features resulting from different mutations in Finnish patients. Kidney Int 2000;58:972-980.

-45 Roselli S, Heidet L, Sich M, Henger A, Kretzler M, Gubler MC, Antignac C: Early glomerular filtration defect and severe renal disease in podocin-deficient mice. Mol Cell Biol 2004;24:550-560.

46 Shih NY, Li J, Karpitskii V, Nguyen A, Dustin ML, Kanagawa O, Miner JH, Shaw AS: Congenital nephrotic syndrome in mice lacking CD2-associated protein. Science 1999;286:312-315.

47 Ma DH, Xu QY, Liu Y, Zhai QQ, Guo MH: Association between interleukin-10 gene polymorphisms and susceptibility to diabetic nephropathy in a Chinese population. Genet Mol Res 2016;15:

-48 Kauppinen TM, Gan L, Swanson RA: Poly(ADP-ribose) polymerase-1-induced NAD(+) depletion promotes nuclear factor-kappaB transcriptional activity by preventing p65 de-acetylation. Biochim Biophys Acta 2013;1833:1985-1991.

-49 Clavijo PE, Frauwirth KA: Anergic CD8+ T lymphocytes have impaired NF-kappaB activation with defects in p65 phosphorylation and acetylation. J Immunol 2012;188:1213-1221.

-50 Zhang J, Zhang Y, Xiao F, Liu Y, Wang J, Gao H, Rong S, Yao Y, Li J, Xu G: The peroxisome proliferator-activated receptor gamma agonist pioglitazone prevents NF-kappaB activation in cisplatin nephrotoxicity through the reduction of p65 acetylation via the AMPK-SIRT1/p300 pathway. Biochem Pharmacol 2016;101:100111. 